\title{
PENGARUH RASIO INTERMEDIASI MAKROPRUDENSIAL (RIM) TERHADAP PENYALURAN KREDIT DENGAN SUKU BUNGA KREDIT SEBAGAI VARIABEL MODERASI (Studi Pada Bank Umum Konvensional yang Terdaftar Di Bursa Efek Indonesia)
}

\author{
Diah Rosdiana \\ diahrosdiana03@gmail.com \\ Jurusan Akuntansi Fakultas Ekonomi dan Bisnis, Universitas Mataram \\ Bambang \\ bambang@unram.ac.id \\ Jurusan Akuntansi Fakultas Ekonomi dan Bisnis, Universitas Mataram \\ Iman Waskito \\ waskitoiman@unram.ac.id \\ Jurusan Akuntansi Fakultas Ekonomi dan Bisnis, Universitas Mataram
}

\begin{abstract}
ABSTRAK
Tujuan dari penelitian ini adalah untuk mendeskripsikan pengaruh Rasio Intermediasi Makroprudensial terhadap penyaluran kredit dan pengaruh dari suku bunga kredit sebagai variabel yang memoderasi hubungan antara Rasio Intermediasi Makroprudensial dengan penyaluran kredit pada perbankan konvensional yang terdaftar di Bursa Efek Indonesia tahun 2019. Penelitian ini merupakan penelitian asosiatif kausal dengan pendekatan kuantitatif. Penelitian ini menggunakan data sekunder berupa laporan bulanan pada perusahaan sektor perbankan yang terdaftar di Bursa Efek Indonesia selama tahun pengamatan 2019. Populasi dalam penelitian ini adalah Bank Umum Konvensional yang terdaftar di Bursa Efek Indonesia. Sampel yang digunakan dalam penelitian ini berjumlah 26 sampel perbankan yang diperoleh dengan metode purposive sampling, sehingga diperoleh jumlah observasi sebanyak 156 observasi selama enam bulan penelitian. Pengujian hipotesis menggunakan SmartPLS 3.0. Hasil dari penelitian ini menunjukkan bahwa Rasio Intermediasi Makroprudensial tidak berpengaruh terhadap penyaluran kredit dan suku bunga kredit tidak mampu memoderasi hubungan antara Rasio Intermediasi Makroprudensial dengan penyaluran kredit.

Kata Kunci : Rasio Intermediasi Makroprudensial, penyaluran kredit, suku bunga kredit ABSTRACT

The purpose of this study is to explain the effect of the Macroprudential Intermediation Ratio on lending and the effect of credit interest rates as a variable that moderates the relationship between the Macroprudential Intermediation Ratio and lending in conventional banks listed on the Indonesia Stock Exchange in 2019. This research is a causal associative study with a quantitative approach. This study uses secondary data in the form of monthly reports on banking sector companies listed on the Indonesia Stock Exchange during the 2019. The population in this study are conventional commercial banks listed on the Indonesia Stock Exchange. The sample used in this study amounted to 26 banking samples obtained by purposive sampling method, in order to obtain a total of 156 observations during the six months of the study. The results of this study indicate that the Macroprudential Intermediation Ratio has no effect on lending. The results also showed that credit interest rates are unable to
\end{abstract}


moderate the relationship between the Macroprudential Intermediation Ratio and lending.

Keywords: Macroprudential Intermediation Ratio, lending, loan interest rates

\section{PENDAHULUAN}

Perbankan merupakan bagian yang penting yang berperan dalam pembangunan ekonomi suatu negara. Perbankan memiliki fungsi sebagai lembaga intermediasi yang tugasnya menghimpun dana dari masyarakat dan menyalurkannya lagi kepada masyarakat dalam bentuk kredit (Putri dan Akmalia, 2016). Kredit merupakan alokasi dana yang terbesar bagi bank yang juga memberi keuntungan yang besar bagi bank. Namun meskipun demikian, risiko yang dihadapi bank dalam penyaluran kredit juga terbilang besar.

Penyaluran kredit yang terlalu tinggi ataupun terlalu rendah dari suatu bank dapat menyebabkan terjadinya resioko sistemik. Berdasarkan PBI 16/11/PBI/2014 tentang Pengaturan dan Pengawasan Makroprudensial, risiko sistemik didefinisikan sebagai potensi instabilitas akibat terjadinya gangguan yang menular (contagion) pada sebagian atau seluruh sistem keuangan karena interaksi dari faktor ukuran (size), kompleksitas usaha (complexity), keterkaitan antar institusi dan/atau pasar keuangan (interconnectedness), serta kecenderungan perilaku yang berlebihan dari pelaku atau institusi keuangan untuk mengikuti siklus perekonomian (procyclicality).

Resiko sistemik tersebut perlu dimitigasi karena dapat berpotensi menyebabkan terjadinya krisis. Untuk itu Bank Indonesia, Kementrian Keuangan, Otoritas Jasa Keuangan, dan Lembaga Penjamin Simpanan bersama-sama mengambil langkah preventif untuk mencegah terjadinya hal tersebut dengan membuat suatu kebijakan yang dapat memitigasi resiko sistemik yakni kebijakan makroprudensial. Kebijakan makroprudensial terdiri dari beberapa instrumen, yakni Loan to Value, Counterciclycal Buffer, dan Ratio Intermediasi Makroprudensial.

Pada semester awal 2019, sistem keuangan Indonesia dihadapkan pada kerentanan yang berpotensi mengganggu ketahanan sistem keuangan, yakni terjadinya pelemahan kinerja korporasi akibat melemahnya perekonomian global yang menyebabkan permintaan kredit menurun sehingga pertumbuhan kredit melambat. Pada semester I 2019 pembiayaan perekonomian hanya tumbuh sebesar 9,62\% (yoy), melambat dibandingkan semester I dan II 2018 yang masing-masing tumbuh sebesar $11,80 \%$ dan 12,56\% (yoy).Sedang pada Juni 2019 Kredit tumbuh melambat ke kisaran 9,92\% (yoy). Secara sektoral, kontraksi pertumbuhan kredit tersebut terutama bersumber dari sektor perdagangan, lain-lain dan industri pengolahan, yang terdampak perang dagang antara Amerika Serikat dan Tiongkok.

Penurunan kinerja korporasi mendorong perbankan cenderung berhati-hati dan selektif dalam melakukan proses intermediasi. Begitu juga dari sektor korporasi yang menahan diri dalam melakukan ekspansi usaha dan berupaya tidak menambah utang sebagai antisipasi risiko ke depan. Kondisi tersebut dikombinasi dengan potensi funding gap akibat pertumbuhan dana pihak ketiga yang masih lebih rendah dari pertumbuhan kredit sehingga pertumbuhan kredit secara agregat menjadi lambat (Kajian Bank Indonesia, 2019). Terkait dengan hal tersebut, Bank Indonesia, memperkuat kebijakan makroprudensial melalui penyesuaian kisaran batas bawah dan batas atas yang digunakan dalam pemenuhan RIM dan RIM Syariah (Kajian Bank Indonesia, 2019).

RIM berasal dari LDR (Loan to Funding Ratio) yang mengalami penambahan komponen surat-surat berharga pada perhitungannya di tahun 2018. LDR sendiri diduga 


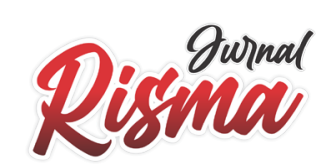

Vol. 1 No. 4 Desember 2021

menjadi salah satu faktor yang mempengaruhi tingkat penyaluran kredit (Afril, 2019; Achmad, 2019; Resa, 2017; Susiana, 2019; Yua, 2106; Prananta, 2019), dimana semakin besar LDR maka semakin besar kredit yang disalurkan (Panuntun, 2018).

Penelitian yang dilakukan Prananta (2019: 109) mengatakan bahwa terdapat pengaruh signifikan antara LDR dengan penyaluran kredit. Hasil yang sama ditunjukkan oleh penelitian (Resa Rausar Ranitasari) bahwa LDR berpengaruh terhadap penyaluran kredit. Adnan (2019) dan Susiana (2019) juga mengatakan bahwa LDR berpengaruh positif terhadap penyaluran kredit. Namun, hasil berbeda malah ditunjukkan pada saat LDR berubah menjadi LFR, dimana LFR memiliki hubungan negatif terhadap penyaluran kredit (Achmad :2019).

Dilihat dari penelitian sebelumnya, rata-rata LDR memberikan pengaruh positif terhadap penyaluran kredit sedangkan saat terjadi perubahan rasio LDR menjadi LFR hasil yang ditunjukkan berbeda. Adanya penambahan komponen dalam LFR dapat menjadi penyebab perbedaan hasil penelitian tersebut. Pertanyaan baru pun muncul untuk rasio yang baru terbentuk di tahun 2018 yakni RIM. RIM, juga memiliki komponen yang berbeda dengan rasio-rasio sebelumnya sebagai bentuk penyesuaian terhadap kondisi ekonomi. Hal tersebut membuat peneliti tertarik untuk meneliti rasio ini, adanya perbedaan komponen akankah memberikan pengaruh terhadap penyaluran kredit. Pelonggaran batas atas dan bawah RIM juga diduga akan mempengaruhi penyaluran kredit.

Selain RIM, faktor yang diduga mempengaruhi penyaluran kredit adalah tingkat suku bunga kredit. Nasabah dalam mengajukan kredit pada umumnya membandingkan tingkat bunga pinjaman (Panuntun, 2018). Tingginya bunga pinjaman yang ditetapkan selain berdampak pada keuntungan yang didapat berdampak pula pada penurunan penyaluran kredit (Susiana, 2019). Bagian kredit bertugas menyalurkan dana sebanyak mungkin agar mampu meningkatkan pendapatan bunga. Namun hukum permintaan juga berlaku dalam perbankan, yakni jika suku bunga kredit tinggi akan menurunkan minat masyarakat untuk mengajukan kredit. Persaingan antar bank menyebabkan nasabah mempunyai banyak pilihan dalam mengambil kredit. Oleh karena itu, bagian kredit dapat menyalurkan kredit dalam jumlah besar jika suku bunga kredit bersaing dengan perbankan lainnya, artinya semakin tinggi tingkat suku bunga kredit akan menurunkan penyaluran kreditnya (panuntun:2018).

Selain itu, suku bunga kredit merupakan salah satu kebijakan moneter, yang mana seperti yang diketahui bahwa kebijakan moneter dan kebijakan makroprudensial juga bisa bersinergi. Salah satunya pada saat perekonomian lambat kedua kebijakan ini dapat memacu pertumbuhan kredit dengan cara menurunkan tingkat suku bunga dari sisi kebijakan moneter dan melonggarkan persyaratan dari sisi makroprudensial (Bank Indonesia, 2016:21). Kebijakan tersebut tentunya dapat meningkatkan minat masyarakat untuk mengajukan kredit. Berdasarkan hal tersebut peneliti tertarik menambahkan satu variabel lagi sebagai variabel pemoderasi yakni suku bunga kredit. Sehingga judul penelitian ini adalah Pengaruh Rasio Intermediasi Makroprudensial (RIM) Terhadap Penyaluran Kredit dengan Suku Bunga Kredit Sebagai Variabel Moderasi (Studi Pada Bank Umum Konvensional yang Terdaftar Di Bursa Efek Indonesia) .

\section{KERANGKA TEORITIS DAN PENGEMBANGAN HIPOTESIS Kerangka Teoritis}

Menurut Jensen and Mackling (1976) hubungan keagenan merupakan sebuah kontrak dimana satu atau lebih orang (prinsipal) memerintah orang lain untuk 
melakukan suatu jasa atas nama prinsipal serta memberi wewenang kepada agen membuat keputusan yang terbaik bagi prinsipal. Teori keagenan dalam penelitian ini ditunjukkan dengan pemerintah sebagai prinsipal dan bank sebagai agen. Mengacu pada kebijakan pemerintah yakni Peraturan Anggota Dewan Gubernur Nomor 21/5/PADG/2019 yang berisi penyesuaian kisaran batas bawah dan batas atas yang digunakan dalam pemenuhan RIM dan RIM Syariah, dari $80 \%$ - 92\% menjadi $84 \%$ 94\%. Kebijakan tersebut ditempuh dalam rangka memperkuat kebijakan makroprudensial yang akomodatif untuk mendorong pertumbuhan kredit atau pembiayaan ekonomi, dengan tetap memperhatikan terjaganya stabilitas sistem keuangan.

Jadi melalui kebijakan tersebut pemerintah (prinsipal) meminta bank (agen) untuk meningkatkan penyaluran kreditnya melalui pemenuhan Rasio Intermediasi Makroprudensial. Pemerintah, dalam hal ini memiliki kepentingan untuk menjaga stabilitas system keuangan melalui penyaluran kredit. Sedangkan bank dengan menyalurkan kredit dapat memperoleh keuntungan. Meskipun begitu, bank tidak sertamerta melakukan hal tersebut dengan mudah, karena bank sebagai agen juga pastinya mempertimbangkan kondisi dari bank itu sendiri. Suku bunga, merupakan salah satu faktor penentu dari minat nasabah dalam mengajukan kredit. Suku bunga pinjaman yang rendah dapat menarik minat masyarakat dalam mengambil kredit. Namun, disisi lain bunga simpanan juga akan berimbas sehingga bank juga memerlukan strategi yang tepat dalam meningkatkan penyaluran kreditnya.

\section{Bank}

Menurut Undang-Undang Nomor 10 Tahun 1998 tentang Perbankan, yang dimaksud dengan BANK adalah "badan usaha yang menghimpun dana dari masyarakat dalam bentuk simpanan dan menyalurkannya kepada masyarakat dalam bentuk kredit dan atau bentuk-bentuk lainnya dalam rangka meningkatkan taraf hidup rakyat banyak." Pada dasarnya Bank dapat juga diartikan sebagai lembaga yang memediasi antara pihak surplus dana dengan pihak defisit dana. Pihak surplus dana adalah masyarakat yang memiliki uang lebih yang dapat disimpan di Bank dalam bentuk: giro, deposito, dan tabungan. Sedangkan pihak defisit dana adalah masyarakat yang mengalami kekurangan dana yang dapat dipenuhi dengan cara meminjam di Bank dalam bentuk kredit (loan) (Syaifuddin, 2007).

\section{Kredit}

Secara etimologi istilah kredit berasal dari bahasa latin, yaitu kata latin credo berarti saya percaya (I trust). Kata itu sebenarnya terbentuk dari dua kata asing yaitu crad dari bahasa Sansekerta yang berarti percaya (trust) dan do dari bahasa Latin yang bermakna menempatkan (to place).... Dengan demikian, akan lebih mudah dipahami bahwa kredit dilandasi oleh kepercayaan yang ditempatkan seseorang lain. Kepercayaan tersebut bersifat timbal balik. Tidak saja pihak pemberi kredit yang menaruh kepercayaan pada pihak yang menerima kredit (Latumaerissa, 1999). Penerima kredit juga menaruh kepercayaan terhadap pemberi kredit. Dalam pemberian kredit juga dikenakan jasa pinjaman kepada penerima kredit (debitur) dalam bentuk bunga dan biaya administrasi (Kasmir, 2012: 25).

\section{Suku Bunga Kredit}

Bunga bank dapat diartikan sebagai balas jasa yang diberikan oleh bank yang berdasarkan prinsip konvensional kepada nasabah yang membeli atau menjual produknya. Bunga dapat diartikan sebagai harga yang harus dibayar kepada nasabah (yang memiliki simpanan) dengan yang harus dibayar oleh nasabah kepada bank 


\section{Risimac}

Vol. 1 No. 4 Desember 2021

(nasabah) yang memperoleh pinjaman. Dalam kegiatan perbankan sehari-hari ada dua macam bunga yang diberikan kepada nasabahnya yaitu sebagai berikut (Kasmir, 2012: 114).

a Bunga simpanan: bunga yang diberikan sebagai rangsangan atau balas jasa bagi nasabah yang menyimpan uangnya di bank. Bunga simpanan merupakan harga yang harus dibayar bank kepada nasabahnya. Sebagai contoh jasa giro, bunga tabungan, dan bunga deposito.

b Bunga pinjaman: bunga yang diberikan kepada para peminjam atau harga yang RIM harus dibayar nasabah peminjam kepada bank. Sebagai contoh bunga kredit.

Menurut Peraturan Bank Indonesia Nomor 20/4/PBI/2018, Rasio Intermediasi Makroprudensial yang selanjutnya disingkat RIM adalah rasio hasil perbandingan antara:

a. Kredit yang diberikan dalam rupiah dan valuta asing; dan

b. Surat berharga korporasi dalam rupiah dan valuta asing yang memenuhi persyaratan tertentu, yang dimiliki BUK, terhadap:

- DPK BUK dalam bentuk giro, tabungan, dan simpanan berjangka/deposito dalam rupiah dan valuta asing, tidak termasuk dana antar bank; dan

- Surat berharga dalam rupiah dan valuta asing yang memenuhi persyaratan tertentu, yang diterbitkan oleh BUK untuk memperoleh sumber pendanaan.

\section{Rerangka Konseptual}

Bank dalam menjalankan fungsinya sebagai lembaga intermediasi menjaga stabilitas sistem keuangan dengan pemenuhan rasio yang telah ditetapkan oleh pemerintah. Pemerintah dalam hal ini melonggarkan RIM dengan maksud meningkatkan penyaluran kredit dari perbankan. Hal tersebut dilakukan tentunya demi menjaga stabilitas sistem keuangan negara. Implikasi teori keagenan dalam hal ini untuk menjelaskan variabel-variabel yang digunakan dalam penelitian ini yaitu RIM (Rasio Intermediasi Makroprudensial) dan suku bunga kredit. Variabel-variabel ini menjadi perintah dari prinsipal untuk dijalankan oleh agen dengan tujuan meningkatkan penyaluran kredit.Berdasarkan hal tersebut rerangka konseptual penelitian ini digunakan sebagai panduan, pola pikir, serta dasar perumusan hipotesis ditunjukkan dalam gambar 1 berikut :

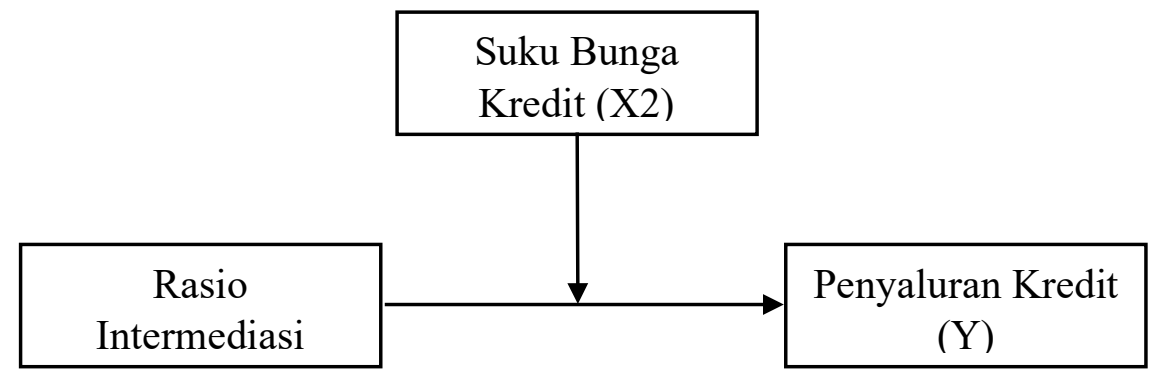

Gambar 1 Rerangka Konseptual

\section{Pengembangan Hipotesis}

Seperti yang diketahui, RIM berasal dari LDR, dimana LDR sendiri merupakan salah satu faktor yang mempengaruhi penyaluran kredit (Putri dan Akmalia (2016); Prananta dkk (2019); Harmayati dan Rahayu (2019); Adnan dkk (2016); Ranitasari (2017); Fildzah dan Adnan (2018); Jayanti (2019)). LDR merupakan ukuran besarnya disbanding dengan dana pihak ketiga, artinya semakin besar LDR semakin besar kredit yang disalurkan (Panuntun, 2018). 
RIM sendiri merupakan perluasan komponen dari rasio-rasio sebelumnya yakni LDR dan LFR. RIM adalah rasio hasil perbandingan antara kredit yang diberikan dan surat berharga korporasi, terhadap DPK BUK dan surat berharga yang diterbitkan oleh BUK untuk memperoleh sumber pendanaan. Kisaran batas bawah dan batas atas yang digunakan dalam pemenuhan RIM84\% - 94\% sesuai dengan PADG 21/5/PADG/2019. Untuk memenuhi aturan tersebut, maka bank perlu menaikkan rasio RIM selama rasio RIM bank tersebut belum memenuhi kisaran batas RIM, maka jumlah penyaluran kredit juga akan ditingkatkan. Sebaliknya apabila rasio RIM bank tersebut sudah terlalu besar melebihi batas atas, maka perusahaan perbankan berusaha menurunkan RIM, maka diikuti pula jumlah penyaluran kredit yang semakin menurun. Oleh karena itu, apabila RIM ingin ditingkatkan sesuai aturan yang berlaku, maka jumlah kredit yang disalurkan pun akan meningkat namun apabila rasio RIM turun maka hal tersebut menyebabkan jumlah kredit juga akan menurun. Dengan demikian hipotesis yang diajukan adalah sebagai berikut:

H1: Rasio Intermediasi Makroprudensial berpengaruh terhadap penyaluran kredit.

Suku bunga kredit merupakan salah satu faktor yang menentukan minat nasabah dalam mengajukan kredit. Nasabah dalam mengajukan kredit pada umumnya membandingkan tingkat bunga pinjaman (Panuntun, 2018). Tingginya bunga pinjaman yang ditetapkan selain berdampak pada keuntungan yang didapat berdampak pula pada penurunan Penyaluran Kredit (Susiana, 2019). Bagian kredit bertugas menyalurkan dana sebanyak mungkin agar mampu meningkatkan pendapatan bunga. Namun hukum permintaan juga berlaku dalam perbankan, yakni jika suku bunga kredit tinggi akan menurunkan minat masyarakat untuk mengajukan kredit. Persaingan antar bank menyebabkan nasabah mempunyai banyak pilihan dalam mengambil kredit. Oleh karena itu, bagian kredit dapat menyalurkan kredit dalam jumlah besar jika suku bunga kredit bersaing dengan perbankan lainnya, artinya semakin tinggi tingkat suku bunga kredit akan menurunkan penyaluran kreditnya (Panuntun: 2018).

Pernyataan di atas sejalan dengan penelitian yang dilakukan oleh Ramelda (2017) yang menemukan pengaruh negatif suku bunga kredit terhadap penyaluran kredit. Sedang Wulansari (2019) menemukan suku bunga kredit memiliki pengaruh yang tidak signifikan terhadap penyaluran kredit. Dengan demikian hipotesis yang diajukan adalah sebagai berikut

H2: Suku bunga kredit dapat memoderasi hubungan antara Rasio Intermediasi Makroprudensial dengan penyaluran kredit.

\section{METODE PENELITIAN}

Jenis penelitian yang digunakan dalam penelitian ini adalah penelitian asosiatif kausal dengan pendekatan kuantitatif. Menurut Sugiyono (2018:20) penelitian asosiatif merupakan penelitian yang bermaksud menggambarkan dan menguji hipotesis hubungan dua variabel atau lebih. Hubungan kausal adalah hubungan yang bersifat sebab akibat dimana terdapat variabel independen (variabel yang mempengaruhi) dan variabel dependen (variabel yang dipengaruhi). Menurut Sugiyono (2018:21) penelitian kuantitatif dapat disebut sebagai metode positivistic karena berlandaskan pada filsafat positivism. Penelitian ini dilakukan pada Bank Umum Konvensional yang terdaftar di Bursa Efek Indonesia dengan menggunakan data yang diperoleh dari website resmi Bursa Efek Indonesia selama 6 bulan dimulai dari bulan Juli sampai Desember 2019. Populasi dalam penelitian ini mencakup seluruh Bank Umum Konvensional yang terdaftar di Bursa Efek Indonesia. Sampel diambil menggunakan metode purposive 


\section{Risimac}

Vol. 1 No. 4 Desember 2021

sampling sehingga diperoleh sampel yang memenuhi kriteria sebanyak 26 Bank Umum Konvensional yang terdaftar di BEI dan didapat jumlah observasi sebanyak 156 observasi.

Jenis data yang digunakan dalam penelitian ini adalah data kuantitatif. Sumber data yang digunakan dalam penelitian ini adalah data sekunder yaitu laporan keuangan bulanan bank yang diperoleh melalui website resmi masing-masing Bank Umum Konvensional, dan melalui website Otoritas Jasa Keuangan. Variabel dependen dalam penelitian ini adalah penyaluran kredit, yang dalam hal ini adalah jumlah kredit yang disalurkan oleh bank dan jumlah surat berharga yang dimiliki oleh bank. Nilai penyaluran kredit ini nantinya akan di Ln pada pengolahan data sebab adanya selisih data tiap perbankan yang terlalu besar sehingga untuk menghindari distribusi data yang tidak normal digunakan Ln. Variabel independent dalam penelitian ini adalah Rario Intermediasi Makroprudensial (RIM). RIM dihitung dengan membangingkan jumlah dari kredit dan surat berharga yang dimiliki dengan jumlah dari DPK (Dana Pihak Ketiga) dan surat berharga yang diterbitkan. Variabel moderasi dalam penelitian ini adalah suku bunga kredit. Suku bunga kredit dihitung dengan menggunakan nilai ratarata suku bunga yang sudah di standardize.

Teknik pengumpulan data yang digunakan yaitu teknik dokumentasi. Dalam hal ini dokumen yang dikumpulkan adalah laporan tahunan, laporan keuangan, serta laporan bulanan yang diterbitkan oleh Bank Umum Konvensional yang terdaftar di BEI. Analisis data untuk pengujian hipotesis dalam penelitian ini yaitu dengan menggunakan aplikasi software SmartPLS 3.0. PLS (Partial Least Square) merupakan analisis persamaan struktural berbasis varian yang secara simultan dapat melakukan pengujian model pengukuran sekaligus pengujian model struktural.

\section{Hasil dan Pembahsan \\ Pengujian model pengukuran reflektif}

Tabel 1

Construct Reliability dan Validity

\begin{tabular}{|c|r|l|r|}
\hline \multicolumn{5}{|c|}{ Construct Reliability and Validity } \\
\hline & \multicolumn{2}{|c|}{$\begin{array}{l}\text { Composite } \\
\text { Reliability }\end{array}$} & $\begin{array}{l}\text { Average Variance } \\
\text { Extracted (AVE) }\end{array}$ \\
\hline PK & 1 & 1 & 1 \\
\hline RIM & 1.11 & 0.991 & 0.957 \\
\hline SKD & 0.944 & 0.949 & 0.757 \\
\hline SUKU INTERAKSI & 1 & 1 & 1 \\
\hline
\end{tabular}

Pengukuran untuk diagram dengan model peubah kurang lebih sama, yaitu pertama menilai konsistensi internal. Nilai konsistensi internal dapat dilihat melalui Composite Reliability. Terlihat nilai Composite Reliability sebesar 1 untuk PK, 0.991 untuk RIM, 0.949 untuk SKD, dan 1 untuk SUKU INTERAKSI. Artinya seluruh variabel menunjukkan konsistensi internal yang baik karena nilai minimal untuk dikatakan baik adalah 0.5 (Fornell dan Larcker,1981).

Tabel 2

Nilai Outer Loading

\begin{tabular}{|l|r|r|r|c|}
\hline \multicolumn{5}{|c|}{ Outer Loading } \\
\hline & PK & RIM & SKD & $\begin{array}{c}\text { SUKU } \\
\text { INTERAKSI }\end{array}$ \\
\hline PK1 & 1 & & & \\
\hline
\end{tabular}


Diah Rosdiana, dkk: Pengaruh Rasio Intermediasi Makroprudensial (RIM) Terhadap Penyaluran.....

\begin{tabular}{|l|r|r|r|r|}
\hline \multicolumn{5}{|c|}{ Outer Loading } \\
\hline PK2 & 1 & & & \\
\hline PK3 & 1 & & & \\
\hline PK4 & 1 & & & \\
\hline PK5 & 1 & & & \\
\hline PK6 & 1 & & & \\
\hline RIM * SKD & & & & \\
\hline RIM1 & & 0.975 & & \\
\hline RIM2 & & 0.986 & & \\
\hline RIM3 & & 0.988 & & \\
\hline RIM4 & & 0.973 & & \\
\hline RIM6 & & 0.969 & & \\
\hline SKD1 & & & 0.813 & \\
\hline SKD2 & & & 0.813 & \\
\hline SKD3 & & & 0.916 & \\
\hline SKD4 & & & 0.92 & \\
\hline SKD5 & & & 0.919 & \\
\hline SKD6 & & & 0.831 & \\
\hline
\end{tabular}

Selanjutnya adalah menilai validitas konvergen yang nilainya dapat dilihat melalui nilai AVE (Tabel 4.7) dan nilai outer loading (Tabel 4.8). Nilai AVE yang dikehendaki adalah $>=0.5$. Sedang untuk nilai outer loading dikatakan baik jika nilainya $>=0.7$ (Chin,1998). Berdasarkan Tabel 4.7 nilai AVE untuk PK sebesar 1, RIM sebesar 0.957, SKD sebesar 0.757. dan SUKU INTERAKSI sebesar 1. Selanjutnya untuk nilai indikator (outer loading) semuanya berada diatas 0.7. Hal tersebut menunjukkan bahwa sebagian besar varian nya berasal dari indikator dan bukan dari galat.

Tabel 3

Discriminant Validity - Nilai Cross Loading

\begin{tabular}{|c|c|c|c|c|}
\hline \multicolumn{5}{|c|}{ Cross Loading } \\
\hline & PK & RIM & SKD & $\begin{array}{l}\text { SUKU } \\
\text { INTERAKSI }\end{array}$ \\
\hline PK1 & 1 & 0.106 & -0.35 & 0.19 \\
\hline PK2 & 1 & 0.107 & -0.352 & 0.189 \\
\hline PK3 & 1 & 0.099 & -0.348 & 0.185 \\
\hline PK4 & 1 & 0.096 & -0.349 & 0.185 \\
\hline PK5 & 1 & 0.094 & -0.348 & 0.185 \\
\hline PK6 & 1 & 0.097 & -0.354 & 0.189 \\
\hline RIM * SKD & 0.187 & 0.254 & -0.515 & 1 \\
\hline RIM1 & 0.079 & 0.975 & -0.059 & 0.234 \\
\hline RIM2 & 0.073 & 0.986 & -0.083 & 0.28 \\
\hline RIM3 & 0.046 & 0.988 & -0.06 & 0.243 \\
\hline RIM4 & 0.088 & 0.973 & -0.127 & 0.298 \\
\hline RIM6 & 0.143 & 0.969 & -0.144 & 0.209 \\
\hline
\end{tabular}




\section{Risinaw}

Vol. 1 No. 4 Desember 2021

\begin{tabular}{|l|r|r|r|r|}
\hline \multicolumn{5}{|c|}{ Cross Loading } \\
\hline & \multicolumn{1}{|c|}{ PK } & \multicolumn{1}{l|}{ RIM } & \multicolumn{1}{l|}{ SKD } & \multicolumn{1}{l|}{$\begin{array}{l}\text { SUKU } \\
\text { INTERAKSI }\end{array}$} \\
\hline SKD1 & -0.289 & -0.094 & $\mathbf{0 . 8 1 3}$ & -0.489 \\
\hline SKD2 & -0.275 & -0.121 & $\mathbf{0 . 8 1 3}$ & -0.469 \\
\hline SKD3 & -0.296 & -0.052 & $\mathbf{0 . 9 1 6}$ & -0.432 \\
\hline SKD4 & -0.28 & -0.057 & $\mathbf{0 . 9 2}$ & -0.421 \\
\hline SKD5 & -0.268 & -0.057 & $\mathbf{0 . 9 1 9}$ & -0.411 \\
\hline SKD6 & -0.383 & -0.158 & $\mathbf{0 . 8 3 1}$ & -0.451 \\
\hline
\end{tabular}

Tabel 4

Discriminant Validity - Kriteria Fornell-Lacker

\begin{tabular}{|l|r|r|l|l|}
\hline \multicolumn{5}{|c|}{ Criteria Fornell-Larcker } \\
\hline & \multicolumn{1}{|c|}{} & & \multicolumn{1}{l|}{ SUKU } \\
& PK & RIM & SKD & INTERAKSI \\
\hline PK & $\mathbf{1}$ & & & \\
\hline RIM & 0.1 & $\mathbf{0 . 9 7 8}$ & & \\
\hline SKD & -0.351 & -0.108 & $\mathbf{0 . 8 7}$ & \\
\hline SUKU INTERAKSI & 0.187 & 0.254 & -0.515 & $\mathbf{1}$ \\
\hline
\end{tabular}

Selanjutnya sebagai langkah terakhir dalam pengujian model pengukuran adalah menilai validitas diskriminan. Pengujian validitas diskriminan pada level konstruk menggunakan nilai Criteria Fornell Larcker. Sedangkan pada level indikator menggunakan nilai cross loading. Tabel 4.9 menunjukkan korelasi antara PK dengan PK-1 sampai PK-6 nilainya lebih besar dari korelasi dengan indikator lain. Begitu juga dengan RIM yang korelasinya dengan indikator RIM lebih besar dibanding dengan indikator lain. SKD dan SUKU INTERAKSI juga menunjukkan hal yang sama. Selanjutnya pada level konstruk terlihat korelasi antar peubah masing-masing lebih tinggi dibandingkan dengan peubah lain. Sehingga dapat dikatakan bahwa kriteria nilainya terpenuhi (Barclay dkk,1995 dan Fornell dan Larcker,1981).

Berdasarkan penilaian ketiga penilaian diatas dapat dikatakan bahwa diagram jalur yang dibuat lulus dari uji model pengukuran dan dapat dilanjutkan ke uji selanjutnya yaitu uji model struktural.

\section{Pengujian model struktural}

Tabel 5

Nilai VIF

\begin{tabular}{|l|c|}
\hline \multicolumn{2}{|c|}{ VIF } \\
\hline RIM & PK \\
\hline SKD & 1.07 \\
\hline SUKU INTERAKSI & 1.362 \\
\hline
\end{tabular}

Nilai VIF digunakan untuk menilai apakah terjadi kolinearitas atau tidak. VIF $<=0.2$ atau VIF $>=5$, menunjukkan bahwa dua konstruk mempunyai persoalan kolinearitas. Tabel 4.5 menunjukkan semua nilai VIF diatas 0.2 dan dibawah 0.5 sehingga dapat dikatakan tidak terdapat persoalan kolinearitas. 
Tabel 6

Nilai t-hitung

\begin{tabular}{|l|c|c|}
\hline \multicolumn{1}{|c|}{ Hipotesis } & $\begin{array}{c}\text { Koefisien } \\
(\text { Jalur } \boldsymbol{\beta})\end{array}$ & $\begin{array}{c}\text { T Statistics } \\
(\mid \mathbf{O} / \text { STDEV } \mid)\end{array}$ \\
\hline RIM -> PK & 0.064 & 0.265 \\
\hline SKD - P PK & -0.348 & 1.201 \\
\hline SUKU INTERAKSI -> PK & -0.009 & 0.024 \\
\hline
\end{tabular}

Selanjutnya yaitu melakukan uji-t melalui proses bootstrap. Hasilnya ditunjukkan oleh tabel 4.12. Nilai koefisien jalur menunjukkan arah dari pengaruh variabel eksogen ke variabel endogen. Terlihat nilainya sebesar 0.064 menunjukkan adanya relasi positif antara RIM dan PK. Nilai -0.348 antara SKD dengan PK menunjukkan adanya relasi negatif. Sedangkan untuk relasi antara SUKU INTERAKSI dan PK adalah positif ditunjukkan dengan nilai $(\beta)$ sebesar 0.009 . T Statistik pada tabel menunjukkan nilai $\mathrm{t}$ hitung yang nantinya akan dibandingkan dengan $\mathrm{t}$ tabel. Nilai $\mathrm{t}$ tabel yang digunakan sama dengan nilai t tabel sebelumnya pada pengujian model tanpa peubah moderator yakni sebesar 2.0595. Jika nilai t-hitung $>$ t-tabel maka hipotesis diterima. Sedang sebaliknya, nilai t-hitung $<\mathrm{t}$-tabel maka hipotesis ditolak

Berikut adalah perbandingan nilai t hitung dengan nilai $t$ tabel:

1. Nilai t hitung untuk hipotesis yang menyatakan RIM memiliki pengaruh terhadap PK lebih kecil dibandingkan dengan nilai $t$ tabel yakni $0.265<2.0595$. Dengan demikian H1 ditolak yang berarti bahwa RIM tidak memiliki pengaruh terhadap PK.

2. Nilai t hitung untuk hipotesis yang menyatakan SKD memiliki pengaruh terhadap PK juga lebih kecil dibandingkan dengan nilai t tabel yakni $1.201<2.0595$. Dengan demikian hipotesis ini ditolak yang berarti bahwa SKD tidak berpengaruh terhadap PK.

3. Nilai $\mathrm{t}$ hitung untuk hipotesis yang menyatakan SUKU INTERAKSI dapat memoderasi PK lebih kecil dibandingkan dengan nilai t tabel yakni $0.024<2.0595$. Dengan demikian H2 ditolak. SUKU INTERAKSI dalam hal ini mewakili SKD sebagai variabel moderasi oleh karena itu hasil yang diperoleh menunjukkan bahwa SKD tidak mampu memoderasi hubungan antara RIM terhadap PK.

Dalam hal ini hasil yang digunakan akan berfokus pada hasil perbandingan satu dan tiga karena keduanya merupakan tujuan yang ingin dicapai oleh peneliti. Sedangkan untuk hasil perbandingan dua tidak digunakan karena pengaruh yang dimunculkan merupakan akibat dari adanya SUKU INTERAKSI.

\section{Rasio Intermediasi Makroprudensial Berpengaruh Terhadap Penyaluran Kredit}

Berdasarkan hasil penelitian dapat diketahui bahwa $\mathrm{H} 1$ dari penelitian ini ditolak sehingga dapat diketahui bahwa Rasio Intermediasi Makroprudensial tidak memiliki pengaruh terhadap tingkat penyaluran kredit perbankan. Jika dikatakan RIM berpengaruh terhadap penyaluran kredit, maka kondisi yang akan terjadi adalah berpengaruh positif atau negatif. Berpengaruh positif berarti saat RIM meningkat maka penyaluran kredit juga meningkat begitu pula sebaliknya. Sedangkan berpengaruh negatif berarti saat RIM naik maka penyaluran kredit akan menurun begitu pula sebaliknya.

Bank dalam hal ini juga harus menjaga angka RIM nya pada rentang $84 \%$ - 94\% (PADG Nomor 21/5/PADG/2019) untuk dikatakan aman. Sementara diketahui bahwa bank akan terus berusaha meningkatkan penyaluran kreditnya untuk memperoleh keuntungan yang tinggi pula. Artinya disini untuk meningkatkan penyaluran kreditnya 


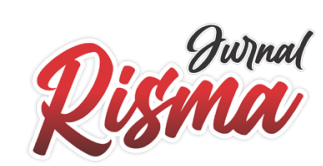

Vol. 1 No. 4 Desember 2021

tentunya RIM juga akan terus meningkat tapi pada kenyataannya RIM tidak bisa terus meningkat ataupun turun melebihi batas yang telah ditentukan. Jika melebihi batas atas maka likuiditas perbankan dikatakan tidak sehat karena tingkat penyaluran kredit dinilai terlalu tinggi tidak sepadan dengan pendanaan yang dimiliki. Selanjutnya nilai RIM yang melebihi batas bawah juga dikatakan tidak baik karena hal tersebut menandakan dana yang dimiliki bank tidak produktif. Oleh sebab itu, disini jelas bahwa bukan RIM yang menyebabkan penyaluran kredit naik ataupun turun. Hal tersebut mendukung hasil penelitian yang menolak hipotesis satu yaitu Rasio Intermediasi Makroprudensial memiliki pengaruh terhadap penyaluran kredit. Hasil penelitian ini sejalan dengan temuan Putri dan Akmalia (2016), Kuncahyono (2016), yang menyatakan rasio ini tidak berpengaruh terhadap penyaluran kredit. Sedangkan Ranitasari (2017), Fildzah dan Adnan (2018) dan Prananta dkk (2019) menemukan hasil berbeda bahwa rasio ini berpengaruh positif terhadap penyaluran kredit.

\section{Suku bunga kredit dapat memoderasi hubungan antara Rasio Intermediasi Makroprudensial dengan penyaluran kredit.}

Berdasarkan hasil penelitian dapat diketahui bahwa $\mathrm{H} 2$ ditolak yang berarti bahwa suku bunga kredit tidak mampu memoderasi hubungan antara Rasion Intermediasi Makroprudensial dengan penyaluran kredit. Seperti yang diketahui bahwa rendahnya suku bunga kredit dapat meningkatkan minat masyarakat untuk mengambil kredit, sehingga dapat meningkatkan penyaluran kredit. Jika melihat kembali ke data yang terjadi di tahun 2019 adalah terjadi penurunan dan kenaikan tingkat suku bunga, sementara penyaluran kredit tetap konstan naik. Sesuai hasil penelitian Selvie (2019) yang menyatakan semakin tinggi atau rendahnya suku bunga, penyaluran kredit akan tetap berada pada level yang konstan. Hal ini bermakna bahwa suku bunga bukan merupakan faktor yang menentukan penyaluran kredit. Hal tersebut didukung juga oleh penelitian lailatul Fitri (2019) yang menyatakan suku bunga kredit tidak berpengaruh terhadap penyaluran kredit. Artinya, peningkatan kredit yang terjadi pada bulan Juli s.d Desember tidaklah disebabkan oleh suku bunga kredit. Sehingga dalam hal ini suku bunga kredit tidak mampu memoderasi hubungan antara RIM dengan suku bunga kredit.

\section{Kesimpulan, Implikasi, dan Keterbatasan}

Simpulan yang diperoleh dari penelitian ini, yaitu:

1. Berdasarkan hasil analisis dan pembahasan diperoleh kesimpulan bahwa Rasio Intermediasi Makroprudensiasl tidak berpengaruh terhadap penyaluran kredit perbankan yang terdaftar di Bursa Efek Indonesia yang tergolong ke dalam papan utama pada periode Juli s.d Desember 2019. Hal tersebut dibuktikan dengan nilai thitung sebesar 0.265 lebih kecil dibandingkan nilai t-tabel sebesar 2.0595. Dengan demikian $\mathrm{H} 1$ ditolak artinya tidak ada pengaruh antara RIM dan PK. Jadi tinggi rendahnya nilai RIM tidak akan memperngaruhi tingkat penyaluran kredit dari suatu perbankan.

2. Berdasarkan hasil analisis dan pembahasan diperoleh juga kesimpulan bahwa suku bunga kredit tidak mampu memoderasi hubungan antara Rasio Intermediasi Makroprudensial dengan penyaluran kredit dari perbankan yang terdaftar di Bursa Efek Indonesia yang tergolong ke dalam papan utama pada periode Juli s.d Desember 2019. Hal tersebut dibuktikan dengan nilai t-hitung sebesar 0.024 lebih kecil dibanding nilai t-tabel sebesar 2.0595. Dengan demikian H2 juga ditolak artinya suku bunga kredit tidak mampu memoderasi hubungan kedua peubah yaitu 
RIM dan PK. Jadi meskipun terjadi peningkatan atau penurunan tingkat suku bunga kredit dari perbankan tidak akan memperngaruhi hubungan antara RIM dan PK.

Hasil dari temuan penelitian ini mempunyai tiga implikasi, yaitu: implikasi teoretis, praktis, dan kebijakan. Implikasi teoritis dari penelitian ini adalah bukti-bukti empiris yang diperoleh terkait RIM, suku bunga kredit dan penyaluran kredit dapat menjadi tambahan literatur untuk penelitian selanjutnya. Implikasi praktisnya dapat memberi manfaat pada berbagai pihak, yaitu bagi Pemerintah dan BI, dapat digunakan sebagai bahan dalam mengevaluasi kebijakan yang dibuat, dimana hasil penelitian ini memberikan informasi terkait dengan hubungan antara RIM dengan penyaluran kredit. Sedangkan bagi pihak manajemen tentunya dapat menjadi tambahan pengetahuan tentang tujuan dari adanya kebijakan RIM itu sendiri. Terakhir, implikasi kebijakan dari penelitian ini adalah pemerintah dan BI dapat menjadikan hasil penelitian ini sebagai bahan pertimbangan dalam membuat kebijakan yang akomodatif yang tentunya melihat senergi dari berbagai faktor pertumbuhan ekonomi sehingga target tujuan dapat dicapai dan terciptanya stabilitas ekonomi.

Hasil penelitian ini dapat berguna bagi penelitian penelitian yang sama di masa yang akan datang, dengan mempertimbangkan beberapa keterbatasan penelitian berikut ini.

1. Periode penelitian yang termasuk singkat, dikarenanakan peneliti ingin melihat bagaimana dampak dari perubahan kebijakan makroprudensial terhadap penyaluran kredit dimana perubahan itu baru terjadi di bulan Juli 2019 sehingga peneliti hanya dapat melakukan pengujian selama setengah tahun dari bulan Juli sampai Desember 2019.

2. Peneliti sudah berusaha mencari laporan keuangan yang dibutuhkan untuk perbankan yang tergolong papan utama di BEI, namun masih ada saja data yang kurang sehingga tidak semua perbankan dalam BEI yang tergolong dalam papan utama dapat dijadikan sampel.

Saran untuk peneliti selanjutnya, yang akan melakukan penelitian yang sejenis. Penelitian dapat dilakukan dengan periode yang lebih lama, atau dapat membandingkan periode sebelum dan sesudah diterapkannya perubahan dari aturan kebijakan makroprudensial tersebut. Peneliti selanjutnya juga dapat menambahkan jumlah sampel penelitian sehingga diharapkan hasilnya dapat lebih akurat. Selain itu yang menarik adalah dalam penelitian ini dapat diketahui bahwa selama periode penelitian yang digunakan, penyaluran kredit terus konstan naik nilainya namun hal tersebut tidak disebabkan oleh suku bunga kredit, sehingga disini peneliti selanjutnya dapat meneliti lebih jauh mengenai faktor apa saja yang mempengaruhi tingkat penyaluran kredit dari perbankan.

\section{Daftar Pustaka}

Adnan, Ridwan, dan Fildzah. 2016. Pengaruh Ukuran Bank, Dana Pihak Ketiga, Capital Adequacy Ratio, dan Loan To Deposit Ratio Terhadap Penyaluran Kredit Pada Perusahaan Perbankan yang Terdaftar Di Bursa Efek Indonesia Tahun 20112015. Jurnal Dinamika Akuntansi dan Bisnis 3(2): 49-64.

Bank Indonesia. 2016. Mengupas Kebijakan Makroprudensial. (www.bi.go.id) diakses tanggal 10 Februari 2020.

Bank Indonesia. 2018. Kajian Stabilitas Keuangan No. 31. (www.bi.go.id) diakses tanggal 19 Januari 2020. 


\section{Risinnar}

Vol. 1 No. 4 Desember 2021

Bank Indonesia. 2019. Kajian Stabilitas Keuangan No. 33. (www.bi.go.id) diakses tanggal 21 Januari 2020.

Fadli, A.A.Y. 2019. Pengaruh Return On Assets (ROA), Liquidity Funding Ratio (LFR), Non Performing Loan (NPL), dan Capital Adequacy Ratio (CAR) Terhadap Penyaluran Kredit Pada Bank Bumn yang Terdaftar di BEI Periode Tahun 2013 - 2017. Business Management Analysis Journal (BMAJ) 2(2): 1-14.

Fildzah, dan Adnan. 2018. Pengaruh Ukuran Bank, Dana Pihak Ketiga, Capital Adequacy Ratio, Dan Loan To Deposit Ratio Terhadap Penyaluran Kredit Pada Perusahaan Perbankan yang Terdaftar Di Bursa Efek Indonesia Tahun 20112015. Jurnal Ilmiah Mahasiswa Ekonomi Akuntansi (JIMEKA) 3(4): 600-6015.

Fitri, L. 2017. Pengaruh Suku Bunga Kredit, Dana Pihak Ketiga (DPK), Dan Giro Wajib Minimum Terhadap Penyaluran Kredit Pada PT. Bank Central Asia, Tbk. Di Indonesia Tahun 2001-2015. JOM Fekon 4(1): 379-392.

Ghozali, Imam. 2015. Structural Equation Modeling Alternatif dengan Partial Least Square (PLS). Semarang: Badan Penerbit Universitas Diponegoro.

Harmayati, W.R., dan D. Rahayu. 2019. Faktor-Faktor Yang Mempengaruhi Penyaluran Kredit Pada Bank Umum Yang Go Publik Di Bursa Efek Indonesia. Jurnal Ekonomi Manajemen dan Akuntansi

Hastuti, S.P. dan Imam, G. 2019. Analisis Faktor-Faktor yang Mempengaruhi Profitabilitas Perbankan Go Public di Indonesia. Diponegoro Journal Of Accounting 8 (3): 1-10.

Jayanti, S.I.D. 2019. Analisis Pengaruh EKUITAS, DPK, ROA, LDR, dan Kredit Macet Terhadap Penyaluran Kredit Perbankan Tahun 2011-2017. Skripsi. Program Studi Ilmu Ekonomi Studi Pembangunan Fakultas Ekonomi Dan Bisnis Universitas Muhammadiyah Surakarta. Surakarta.

Jensen, M.C. And William, H.M. 1976. Theory of The Firm: Managerial Behavior. Agency, Cost an Ownership Structure.Jurnal Of Financial Economics 3(4): 305360 .

Kasmir. 2012. Bank Dan Lembaga Keuangan Lainnya. Jakarta: PT Raja Grafindo Persada.

Kuncahyono, Dwi. 2016. Pengaruh DPK, NPL, CAR, ROA, LDR, dan BOPO Terhadap Penyaluran Kredit (Studi Kasus Bank Umum Go Public di Indonesia Periode 2010 - 2014). Artikel Ilmiah. STIE Perbanas Surabaya

Latumaerissa, J.R. 1999. Mengenal Aspek-Aspek Operasi Bank Umum. Jakarta: Bumi Aksara

Otoritas Jasa Keuangan. 2016. Perbankan. OJK. Jakarta.

Panduan Go Public Bursa Efek Indoneseia Pdf (www.idx.co.id diakses tanggal 11 April 2020)

Panuntun, B., dan Sutrisno. 2018. Faktor Penentu Penyaluran Kredit Perbankan Studi Kasus Pada Bank Konvensional di Indonesia. Jurnal Riset Akuntansi dan Keuangan Dewantara 1(2): 57-66.

Peraturan Anggota Dewan Gubernur Nomor 21/5/PADG/2019 Perubahan Ketiga Atas Peraturan Anggota Dewan Gubernur Nomor 20/11/PADG/2018 Tentang Rasio Intermediasi Makroprudensial Dan Penyangga Likuiditas Makroprudensial Bagi Bank Umum Konvensional, Bank Umum Syariah, Dan Unit Usaha Syariah. 29 Maret 2019. Jakarta. 
Peraturan Bank Indonesia Nomor 16/11/PBI/2014Pengaturan dan Pengawasan Makroprudensial. 1 Juli 2014. Lembaran Negara Republik Indonesia Tahun 2014 Nomor 141 DKMP. Jakarta.

Peraturan Bank Indonesia Nomor 17/11/PBI/2015 Perubahan Atas Peraturan Bank Indonesia Nomor 15/15/PBI/2013 tentang Giro Wajib Minimum Bank Umum Dalam Rupiah Dan Valuta Asing Bagi Bank Umum. 25 Juni 2015. Lembaran Negara Republik Indonesia Tahun 2015 Nomor 152 DKMP. Jakarta.

Peraturan Bank Indonesia Nomor 20/4/PBI/2018 Rasio Intermediasi Makroprudensial Dan Penyangga Likuiditas Makroprudensial Bagi Bank Umum Konvensional, Bank Umum Syariah, Dan Unit Usaha Syariah. 13 April 2018. Lembaran Negara Republik Indonesia Tahun 2018 Nomor 44. Jakarta.

Prananta, W., Yulianti, dan A. Damajanti. 2019. Pengaruh Kinerja Keuangan Terhadap Penyaluran Kredit Pada Bank Perkreditan Rakyat Di Kota Semarang. Jurnal Riset Ekonomi dan Bisnis 10(2): 99-111.

Putri, Y.M.W. dan A. Akmalia. 2016. Pengaruh CAR, NPL, ROA DAN LDR Terhadap Penyaluran Kredit Pada Perbankan (Studi Pada Perusahaan Perbankan yang Listed di Bursa Efek Indonesia Periode 2011-2015). Jurnal Balance 13(2): 8293.

Ramelda, S. 2017. Pengaruh Suku Bunga Kredit Dan Produk Domestik Bruto Terhadap Penyaluran Kredit Perbankan Bank Umum Pemerintah di Indonesia. Jurnal Online Mahasiswa Fakultas Ekonomi 4(1): 828-842.

Ranitasari, Resa Rausar. 2017. Pengaruh DPK, LDR, CAR, NPL, dan NIM Terhadap Penyaluran Kredit Pada Perusahaan Perbankan Swasta Devisa Nasional yang Terdaftar di Bank Indonesia Periode 2011-2015. Artikel Ilmiah. STIE Perbanas Surabaya

Santosa, P.I. 2018. Metode Penelitian Kuantitatif Pengembangan Hipotesis dan Pengujiannya Menggunakan SmartPLS. Yogyakarta; Penerbit ANDI.

Selvie, S., M. Arfan, dan S. Abdullah. 2017. Pengaruh Dana Pihak Ketiga, Suku Bunga Kredit, Dan Modal Bank Terhadap Penyaluran Kredit Pada Bank Perkreditan Rakyat Konvensional di Indonesia. Jurnal Magister Akuntansi 6(2): 52-58.

Selvie, S., Muhammad, A., Syukriy. A. 2017. Pengaruh Dana Pihak Ketiga, Suku Bunga Kredit, Dan Modal Bank Terhadap Penyaluran Kredit Pada Bank Perkreditan Rakyat Konvensional Di Indonesia. Jurnal Magister Auntansi Pascasarjana Universitas Syiah Kuala 6(2): 52-58.

Situs Bursa Efek Indonesia (www.idx.co.id)

Sugiyono. 2018. Metode Penelitian Bisnis : Kuantitatif, Kualitatif, dan R\&D. Bandung: Alfabeta.

Syaifuddin, D.T. 2007. Manajemen Perbankan (Pendekatan Praktis). Kendari: Unhallu Press.

Wulansari, E.D., R. Jonathan, dan B. Tandierung. 2019. Analisis Pengaruh Dana Pihak Ketiga (DPK), dan Tingkat Suku Bunga Kredit Terhadap Penyaluran Kredit Modal Kerja Pada PT. Bank Pembangunan Daerah Kaltimtara di Samarinda. Jurnal Akuntansi dan Manajemen 8(3): 1-14. 